Article

\title{
Effects of the Concept of the Dualist Division of Lakes in Polish Law on Shaping Lake Water Policy from the Hydrological Perspective
}

\author{
Włodzimierz Marszelewski ${ }^{1}$ and Michał Marszelewski ${ }^{2, *}$ \\ 1 Faculty of Earth Sciences, Nicolaus Copernicus University in Toruń, 87-100 Toruń, Poland; marszel@umk.pl \\ 2 Faculty of Law and Administration, Nicolaus Copernicus University in Torun, 87-100 Torun, Poland \\ * Correspondence: marszelewski@gmail.com; Tel.: +48-603-261-000
}

Received: 11 September 2018; Accepted: 21 October 2018; Published: 23 October 2018

\begin{abstract}
Pursuant to the Polish Water Law Act of 2017, lakes are divided into those with flowing and stagnant waters. Such a division, originating from the socialist law, is questioned in the scope of numerous disciplines. One of them is hydrology. The legal division introduces criteria uncertain from the hydrological point of view, incomplete, unclear, and difficult to apply. This results in further problems in the implementation of water policy and in the socio-economic sphere. The latter particularly concerns expensive and long-lasting court proceedings, fear of losing ownership of lakes with no financial compensation, and the uncertainty of the binding law. This has a significant impact on the broadly understood management of water resources, such as fisheries, recreation, and water protection. The paper covers a comprehensive analysis and evaluation of Polish legal solutions from a hydrological and water policy perspective. Moreover, it presents the comparison of Polish law and selected legal orders in the scope of ownership of lakes.
\end{abstract}

Keywords: water policy; lake ownership; water law

\section{Introduction}

Water policy can be discussed in at least several aspects: global, regional, and national. The term "water policy" is defined as systems of water management that are expressed in legal doctrines or governance institutions. Water policy and water law currently comprise different elements such as: local customs and rules, national legislation, regional agreements, and global treaties, as well as global legal governance [1]. Global water policy focuses on the identification of the primary wter issues at the global scale for the purpose of finding solutions permitting sustainable water management, and particularly the improvement of the conditions of human activity and environmental conditions. It is particularly implemented by international governmental and non-governmental (including scientific) organisations based on customary international law and various treaties concerning broadly understood water resources. Pursuant to the above, regional water policy is based on dedicated supranational law and also public and private actors (e.g., within the area of the European Union or transboundary basins). Finally, national water policy is based on national and local law and also national and local public and private actors.

The most difficult task is the implementation and execution of water policy at the global scale. It has to be a result of compromise obtained in many areas. It is somewhat easier to conduct water policy in the international scale, particularly in reference to countries in close mutual cooperation in different areas (e.g., between the Member States of the European Union). The implementation of national and local water policy is undoubtedly the least complicated. Irrespective of the scope of water policy, difficulties and errors in its implementation cause different kinds of conflicts, 
which usually-depending on their rank-concern man to the greatest degree. Example trends of changes in water policy and water law over the last several thousand years and in different parts of the world (including European Union) are discussed in a broad study edited by J.W. Dellapenna and J. Gupta [1,2].

From the point of view of an individual, national water policy is of the most importance. It directly and most substantially affects their situation. The most important tool of development of the policy is undoubtedly the law. In addition to classic bans and orders, it must consider components, phenomena, and processes occurring in the natural environment, and particularly in the water environment. It turns out, however, that the law-even on the national and local level—is not flawless, because it cannot predict all situations resulting from the functioning of the water environment. The general review of selected issues concerning ownership of lakes, partially related to water policy, is presented by W. Block and P.L. Nelson [3].

This article concerns water policy of Poland in the scope of ownership of lakes, raising different kinds of controversies in recent years. They are related to the model of ownership functioning in the past in the socialist system. Its consequences occur until today. Poland as a Member State of the European Union currently develops its own water policy. The policy, however, must correspond with the assumptions of water policy implemented by the European Union. Due to this, it should be in accordance with the EU law, and particularly, with the Water Framework Directive [4]. The issue of ownership of lakes, however, remains outside the interest of the law of the European Union. Potential negative effects of Polish regulations in the scope can raise doubts from the point of view of the EU law. However, they do not justify the thesis on the obvious incoherence of the national law with norms of environmental directives of the European Union.

\section{Materials and Methods}

The article considers Polish legal documents related to water policy (Water Act 1922, Water Law 1962, 1974, 2001, 2017), and for comparison-legislature of the State of Minnesota (Minnesota Statutes 2017) and judicature of American federal and state courts. The analysis also concerned materials included in national and foreign publications regarding water policy in reference to lakes. It also considers cartographic materials as well as own study and field observation results from lake catchments that are related to the preparation of opinions for common courts.

The study employed desk study and field research methods. Desk studies involved comparative research and analyses of legal, literature, and cartographic materials. Field research was implemented for the purpose of determination of the classification of lake waters in terms of Polish law. It covered the determinations of the type of inflows and/or outflows of lakes in hydrological terms (permanent or periodical), and concerned the determination of their genesis (natural or artificial). Information obtained from the local community was also used. Results of field research permitted the comparison of the existing classification of lakes in legal terms with the actual state.

\section{Results}

\subsection{Current and Historical Aspects of Water Policy in Reference to Lakes}

Legal regulations binding in Poland introduce criteria of classification of lakes that do not correspond with their hydrological typology. From the legal point of view, lakes are included either to the category of stagnant or flowing waters. It depends on the fact and way of connection of lakes with other waters through watercourses. Meanwhile, from the hydrological point of view, lakes are classified exclusively as stagnant waters.

The most important consequence of the binding character of the said legal regulations is the exclusion of lakes considered as flowing waters from civil law turnover. As a result, only the State Treasury is entitled to ownership of such lakes. Lakes that are considered as stagnant waters can constitute property of private (e.g., natural persons) as well as public entities (e.g., State Treasury). 
Therefore, the classification of a lake within one of the aforementioned categories determines the possibility of it constituting property of a particular entity. This further translates to among others the way of use of a given lake or its protection. This suggests that legal regulations concerning the classification of lakes constitute an important tool of implementation of water policy of Poland in reference to lakes.

The prototype of the current regulations can be found already in the Water Act of 1922 (Act Reg. of 1922, No. 102, item 336). Pursuant to the act, each lake could constitute private property. Although the act referred to lakes in the context of both stagnant and flowing waters, it introduced no classification criteria. Due to this, the incoherence with the hydrological criterion did not play a significant role in practice.

After World War II, Poland was included in the group of countries with the socialist political system. This resulted in the necessity of adjustment of normative regulations corresponding with the socialist legal system. An example is the Water Act of 1962 (Act Reg. of 1962, No. 34, item 158). It introduced the primacy of state ownership with simultaneous marginalisation of private ownership. This led to the nationalisation of almost all lakes with no financial compensation for their contemporary owners. This occurred through the introduction of imprecise classification criteria. Pursuant to the criteria, each lake was supposed to be assessed and qualified as flowing or stagnant water. Further legal acts regulating the discussed issue, i.e., Water Act of 1974 (Act Reg. of 1974, No. 38, item 230 with further amendments) and Water Act of 2001 (Act Reg. of 2001, No. 115, item 1229 with further amendments) inconsiderably modified the criteria, resulting in the maintenance of the division into stagnant and flowing waters in practice.

Beginning from political system changes in Poland that commenced in 1989, in spite of revoking regulations that were related to the socialist legal system, the legislator did not undertake a revision of the approach to the issue of classification (and ownership) of lakes. As a result, a great majority of lakes still constitutes public property (of the State Treasury), and their purchase by private entities encounters restrictions analogical to those of the socialist system.

In 2017, another Water Act (Act Reg. of 2017, item 1566 with further amendments) was passed, aimed at among others full implementation of directives of the European Union in issues related to broadly defined water management, including water protection. The legislator again maintained solutions developed based on the socialist legal system. It considered them appropriate for the development of modern water policy in the scope of lakes, and in line with requirements resulting from the law of the European Union. Pursuant to art. 22 point 2 of the Water Law of 2017, lakes are classified as inland flowing waters if they have a continuous or periodical inflow and/or outflow of surface waters. Article 23 of the act suggests that lakes should be considered stagnant waters if they are not directly and naturally related to surface inland flowing waters (e.g., rivers). The said division is of exclusive character, and each lake must be classified in the scope of either one or the other category.

\subsection{Conflicts between Legal Norms and Hydrological Conditions in Lake Water Policy}

Classification of lakes in accordance with Polish law occurs based on the aforementioned art. 22 and 23 of Water Law of 2017. Pursuant to legal norms, two criteria must be met for a lake to be classified as flowing water, namely: permanent or periodical inflow and/or outflow, and their natural genesis.

The first criterion is easy to determine in the case of no doubts regarding the permanence of the watercourse. Pursuant to the hydrological definition, a watercourse is a linear hydrographic object designating flowing waters in the form concentrated due to gravity in a natural or artificial channel. If the watercourse is also large (more than several $\mathrm{m}^{3} / \mathrm{s}$ ), in the moderate zone (like in Poland) it occurs throughout the year. Small watercourses (below $1 \mathrm{~m}^{3} / \mathrm{s}$ ) show an evident tendency for drying in the warm half-year, i.e., from May to October. Such watercourses are described as periodical. The smaller the watercourse, however, the higher the frequency of its drying. Small watercourses (including the smallest ones) often do not function for several years in a row. Such watercourses cannot be considered 
periodical, because they do not function regularly. Watercourses flowing once in several or a dozen years and in different seasons of the year should be described as episodic or irregularly flowing watercourses. Meanwhile, lawyers and sometimes hydrologists associate periodical watercourses with episodic ones. In such situations, a serious conflict occurs already at the stage of interpretation of legal norms. As a result, the final classification of a lake is considerably delayed, because it is necessary to implement field research. Results of such research aim at the determination of the actual character of the watercourse. Field research can last even up to several years due to the necessity of evidencing the periodical character of a given watercourse or its lack. Moreover, it is prolonged due to extremely different meteorological conditions occurring in consecutive years in the moderate climate zone. It is particularly evident in the period of climate changes.

It should be emphasised that, in the case of determination of the occurrence of only an episodic watercourse (or episodic watercourses) in a lake catchment, it is not possible to perform its legal classification. An episodic watercourse, even of natural origin, does not refer to any classification criteria of lakes specified in the Water Law of 2017. Due to this, lakes exist that cannot be classified pursuant to legal regulations. Such situations are an example of an exceptionally negative effect of the dualist concept of legal division of lakes.

The second criterion is only seemingly easy to determine. Whereas there is no doubt as for the natural genesis of large watercourses, in the case of small watercourses the situation is completely different. The majority of small watercourses, including the smallest ones, developed as a result of melioration works in the 19th century or earlier. They are usually ditches whose artificial channels transformed to resemble natural channels. This occurred among others in the case of the abandonment of conservation of ditches from the time they lost their importance due to broadly defined economic development. Moreover, no documentation is usually preserved from the period of intensive melioration works due to the lack of continuity of existence of the Polish State from the second half of the 18th century to 1918 (partitions years). All of this makes proper qualification of the genesis of small watercourses difficult. In such situations, hydrological as well as geological research is necessary, permitting the determination of the genesis of a watercourse. This kind of research is expensive, time-consuming, and requires specialist knowledge.

Another conflict concerning classification of lakes-this time in reference to stagnant waters-is related to the requirements of lack of direct natural connection of the lake with the water network. This legal regulation (art. 23 of Water Law of 2017) suggests the possibility of occurrence of also an indirect connection of the lake with the water network. This results in a conflict in the scope of interpretation of the said regulation, because sometimes attempts are undertaken to evidence the existence of an indirect natural connection of a lake with the water network. Meanwhile, from the hydrological point of view, indirect natural connection of lakes with the water network does not exist.

The imprecise criteria of classification of lakes in Polish law result in different and undesirable situations making the implementation of the planned water policy difficult. Situations are common in which the same lake is classified as stagnant or flowing water by different entities (including court experts). An extreme example of a negative effect of the complicated character of legal provisions in the scope of classification of lakes is Lake Radodzierz with an area of $2.46 \mathrm{~km}^{2}$ [5]. Its northern part, located in the territory of the Nowe commune, was qualified as stagnant water, and constitutes private property. The southern part of the lake, which is located in the territory of the Warlubie commune, was classified as flowing water, and it constitutes property of the State Treasury (Figure 1).

Meanwhile, as results from field research that was performed by the authors, Lake Radodzierz is a typical flow-through lake, and (pursuant to the Water Law of 2017) it should be classified as flowing water. The lake has a permanent natural inflow from the neighbouring lakes (point I in Figure 1) and a permanent outflow (point $\mathrm{O}$ in Figure 1). In spite of unambiguous hydrological conditions, the complicated legal status has been hindering proper classification of the lake for almost 10 years. Classification of the lake in both categories is also unacceptable in legal terms, because the classification of lakes in the Water Law of 2017 is of exclusive character. Each lake constitutes one water mass and it 
cannot belong to different categories of waters. Such a situation considerably complicates the fisheries management, with rules of functioning different in the case of private and public waters. The situation is similar in other countries, e.g., in Finland [6].

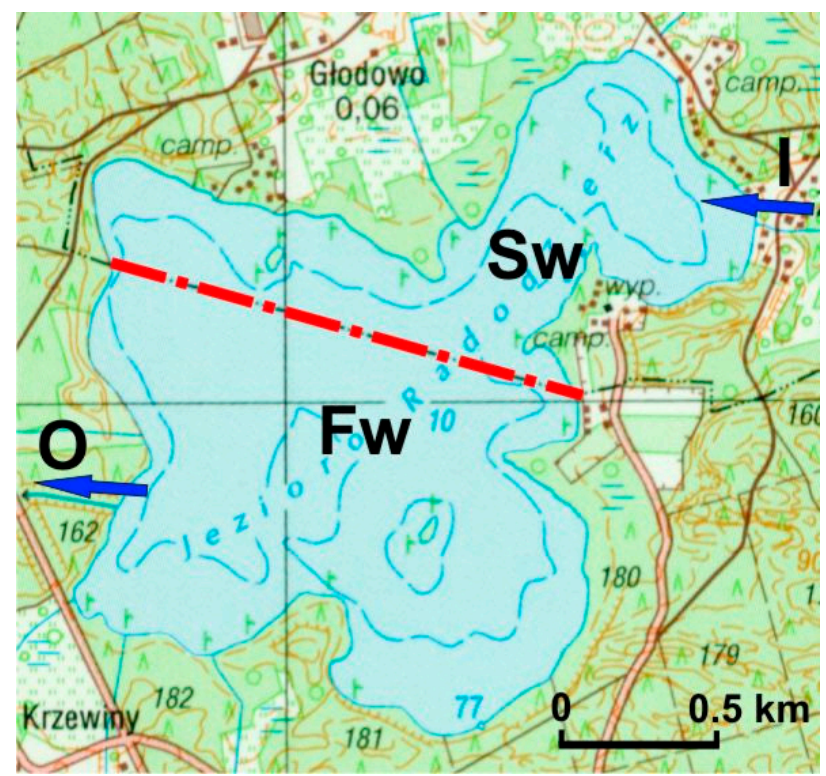

Figure 1. Division of Lake Rododzierz at variance with the Water Law. Sw-stagnant water. Fw-flowing water; I-inflow; O-outflow. Source: topographic maps in scale 1:50,000 (The National Geodetic and Cartographic Resources in Warsaw).

\subsection{Socio-Economic Effects}

The implementation of water policy in reference to lakes in combination with the imprecise criterion of classification of lakes leads to a number of negative effects in the socio-economic sphere. Owners of lakes earlier classified as stagnant waters are private entities. The entities hold the title to lakes as a result of inheritance or purchase. The persons develop a specific group standing out by emotional attachment to a lake and/or economic dependency on it (e.g., fish farmers or owners of recreational resorts). Moreover, the lake constitutes an important element of their property. Therefore, situations in which they learn about the possibility of a change of the lake's classification from stagnant to flowing water (that legally translates into the loss of ownership of the lake) cause various negative effects, including among others stress, reluctance of further investments and proper management of the lake, reluctance to incur financial expenses, aversion to entities related to public administration, and lack of trust to the legal system. One of the latest examples of such a situation is the procedure at the Regional Court in Kartuzy (Pomorskie Voivodship) conducted in the years 2016-2018. The objective of the procedure was to determine the character of the waters of Lake Kielno (file signature I C 1650/16). In this case, a private owner purchased the lake after obtaining a document from the appropriate office of the state administration in 1978 that confirmed the stagnant character of the lake waters. In spite of holding the document and a document confirming the ownership right to the lake, the owner was forced to undertake a number of costly measures. The measures focused on questioning evidence presented by the plaintiff acting on behalf of the State Treasury. Another example of a dispute concerning the character of waters is Lake Strzemiuszczek (Kujawsko-Pomorskie Voivodship). The procedure concerning the lake was conducted at the Regional Court in Brodnica and at the District Court in Torun in the years 2011-2016 (file signature VIII Ca 594/16). The long-lasting court proceedings made proper implementation of planned investments (e.g., recreational infrastructure) difficult for the owner. One of the longest procedures is the dispute concerning Lake Stacinko (Pomorskie Voivodship) conducted in the years 2000-2016. Numerous court hearings were performer at the Regional Court in Kartuzy, followed by those at the Districy Court in Gdańsk and at the Supreme 
Court in Warsaw. Due to numerous irregularities, the Supreme Court revoked the previous ruling unfavourable for the private owner, and submitted the case for another examination at the Regional Court in Kartuzy (file signature IC 848/14). Finally, after presenting the opinion of further experts (including the co-author of this paper), the current classification of the lake (stagnant water), favourable for the private owner, was sustained. The exceptionally long procedure caused social conflicts between the lake's owner and persons supporting his attempts to keep the lake, and the remaining part of the local community. An Association was even founded for the protection of the environment of Lake Stacinko. It joined the dispute against the lake's owner. The conflict has been described in the press and on TV a number of times, which interfered with the privacy of the lake's owner $[7,8]$. This type of situations also concern persons interested in the purchase of a lake. Such persons often give up the intention of purchasing a lake and provision of business activity due to the fear of its loss in unspecified future.

A change of classification of a lake leads to the cancelling of the property right of the current owner. This occurs through court proceedings. The current owner is usually at a risk of incurring high costs of a proxy (e.g., lawyer), and-depending on needs-costs that are related to the preparation of a private hydrological-legal opinion. Based on the authors' observations, a part of private owners of lakes does not have sufficient financial resources, which reduces their chances of winning the dispute.

In the case of loss of ownership of a lake, the property of the owner is subject to a considerable decrease. They receive no compensation from the State Treasury. A private owner can pursue their claims only in the course of civil law proceedings against the person from whom they purchased the lake. This is very difficult in practice, and in the case of inheritance of a lake, virtually impossible. Purchase of a lake improperly classified by different state entities as stagnant water is invalid. The State Treasury is not liable for the activities or negligence of entities that are responsible for proper classification of the waters. An inappropriate decision of such an entity in the scope usually does not result in any liability of either the entity or the supervising entity. The possibility of imposing liability to damages on such entities (in the scope of the existing legal solutions) is difficult to execute. During several years of research on the described issues, the authors never encountered the fact of bearing liability due to improper classification of a lake as stagnant water (at variance with the actual state) providing the basis for the sale of the lake to a private person.

\section{Discussion}

Information and data that are presented in the previous part suggest that from the point of view of Polish water policy, ownership of lakes is one of the most important factors determining lake management. In reference to the above, it is worth citing examples of an approach to ownership of lakes in other countries. This part of the paper provides a short overview of water policy in the scope of ownership of lakes in several countries, particularly the United States of North America. Moreover, this part draws attention to environmental factors making classification of lakes difficult, and proposes methods facilitating classification of lakes pursuant to Polish law.

\subsection{Ownership of Lakes in Selected Countries}

There is no uniform concept related to legal classification and ownership of lakes. In many countries, varied solutions have been developed, often of unique character.

An interesting example of a different approach to the issue of classification and ownership of lakes are solutions applied in the United States. They are characterised by a pragmatic approach. The public or private status of a watercourse is determined by the result of the navigability test [9], and more specifically "the federal test of navigability" [10]. The criteria of the test were specified in the American legislature by the Supreme Court in case The Daniell Ball from 1870 [11]. Pursuant to the criteria, "Rivers are navigable in fact when they are used or are susceptible of being used in their ordinary condition as highways for commerce over which trade and travel are or may be conducted in the customary modes of trade and travel on water" [11]. Although they concern rivers, they should 
be referred to all watercourses [12], and therefore also lakes related to watercourses. Ownership of beds of navigable waters was given to particular states upon joining the Union as a result of transfer of local sovereignty [9]. Such a situation resulted from the fact that thirteen original states obtained the title to beds of navigable waters-at the time defined as waters "affected by the ebb and flow of the tide" - directly from the British Crown. Due to this, it was necessary to apply so-called "equal footing rule" imposed by the Federal Constitution on the new states [13].

The implementation of the aforementioned solution encountered various difficulties for many reasons. The implementation of the English concept of navigable waters in the American legal order, and doubts as for its application are discussed in a paper entitled "The Ownership of Land under Waters" [14]. The resulting conflicts between the federal and state jurisdiction in reference do navigable waters in the second and third decade of the 20th century are presented by M. Starr [15]. Disputes also occurred because some states considered the criteria of classification of waters included in the federal test of navigability as too narrow. It was evidenced that they do not cover all interests of residents of such states [9]. While discussing issues related to navigable waters it should be pointed out that a definition of navigable waters also functioning in the American law is used to define authorities of the Corps of Engineers (Code of Federal Regulations §329.1 and §329.4).

The analysis of judicature performed by P.N. Davis distinguishes two general rules concerning ownership of beds of inland waters (including lakes) that states established from the federal territory are entitled to. The first one concerns the title to the discussed beds of navigable waters and its transition to particular states at the moment of joining the Union. The states can manage the titles in any way. Pursuant to the second rule, beds of inland waters (including lakes) are considered non-navigable according to the federal definition remain at statehood. Exceptions and restrictions concerning the rules are admissible [13].

An example of American solutions on the state level can be the state of Minnesota. Three legal categories of lake waters are designated there, covering all lakes that are located within its territory (a total of 11,842 lakes). The first one are the aforementioned navigable lakes, whose bed ownership was granted to Minnesota by the Federal Government when it became a state in 1858. They are particularly large lakes such as Superior, Leech, or Cass [10]. The second category is meandered lakes (in the period 1851-1973 all lakes with an area of 25 acres or more; now-all lakes with an area of 50 acres or more). Land surrounding such lakes can constitute private or public property. Ownership of land inside the "meandered line" of the lake was not ascribed to a particular owner, and therefore the lake bed is jointly owned by all of the landowners surrounding the lake. In the case of drying of such a lake, the owners can perform a division of the exposed land [10]. The last and most extensive category concerns so-called non-meandered lakes. Land under them belongs to each owner of the surrounding land (developing the shoreline). Due to this, private entities can be owners of beds of such lakes and pay property tax on the lake beds. If such a lake dries up, no complications occur, because such entities are always entitled to land ownership [10]. Due to the separation of ownership of water from ownership of land, water itself in Minnesota is of public character. Everyone can use it, provided that they are able to legally reach the water without trespassing on someone else's land. In the case of failure to obtain permission of the owner of land surrounding a lake, and a lack of possibility of using other options (e.g., road right-of-way), the only way to reach lake waters is access from air [16].

The discussed issue is somewhat different in the state of New York. According to the rule adopted there, the title to lake beds of small lakes is allowed to constitute private property. In a situation of lack of other determinations, the riparian owner is presumed to be entitled to the title [17]. The situation is different in the case of large lakes the title to which was generally granted to the state of New York [18].

The issue of classification and ownership of lakes is an area of interest of many jurisdictions, including European ones. An example can be Lithuania, recently striving towards limiting of private ownership of lakes. This is done through the expansion of the categories of classification of waters as water bodies of national importance [19]. A different approach is represented by Finland, with more 
than 187,000 lakes. Although they occupy as much as $10 \%$ of the area of the country, the majority of inland water areas constitutes private property [20].

\subsection{Environmental Factors Making Classification of Lakes Difficult, Based on The Example of Poland}

In Poland, the most important environmental factors include among others morphometric parameters of the lake (and particularly its size), way of supply of surface waters, and location of the lake in the hydrographic network. Almost all lakes constituting private property are located in upper parts of catchments. This results from earlier classifications of lakes that eliminated private lakes with large watercourses flowing through, including rivers. Private lakes (potentially disputable) are currently closed-drainage lakes or have small periodical or episodic inflows and/or outflows, natural or artificial. Such complexity of the hydrographic situation considerably complicates their legal classification.

One of the main reasons is the great number and variability of lakes as subjects of legal regulations. Each lake is a complex ecosystem, and each lake occurs in different environmental, including hydrological conditions. Therefore, almost any lake should be considered individually, especially that they are subject to transformations particularly manifested in the period of climate warming. One of the effects of climate warming is a transformation of many periodical watercourses into episodic ones. It is important, because, as mentioned earlier, in the case of water supply to the lake through a natural periodical watercourse, Polish law classifies the lake as flowing water. Meanwhile, Polish Water Law from 2017 does not differentiate periodical and episodic watercourses. Due to this, episodic watercourses escape the regulations of the act. This contributed to further complications in the classification of lakes. The legislator should consider changes occurring in the environment that affect water relations. The problem of adjustment of water policy in the period of climate warming and in the situation of changes in rainfall patterns is pointed out by M. Alamaro [21]. In the case of Central Europe (and other areas in the world), increasing evaporation resulting from a strong increase in air temperature is also very important. It contributes to a decrease in water resources in catchments, including a decrease in water supply to lakes.

\subsection{Proposed Methods Facilitating Classification of Lakes Pursuant to Polish Law}

In the situation of different changes occurring in catchments, it is necessary to conduct field research assessing the evolution of the hydrographic components important for the proper classification of lakes. The multi-aspect variability of the assessed actual states considerably hinders the preparation of a universal methodology of classifying lakes according to legal criteria. Due to this, the experience and professionalism of the person classifying the lake is of utmost importance, as well as documents considered in the opinion. A large disproportion simultaneously occurs in the labour intensity related to the classification of lakes. In some cases, desk studies are sufficient. Other cases require observations and field research. Field research should be sometimes conducted for several years due to the high variability of meteorological and hydrological conditions (e.g., dry periods, humid periods).

Important documents that can help explain the genesis of many small watercourses (inflows of lakes) are historical cartographic studies. They present the hydrographic situation from the period preceding many melioration works. It is particularly helpful in documenting the natural or artificial genesis of inflows and/or outflows of lakes. The oldest, highly accurate German maps from the second half of the 19th century at a scale of 1:25,000, the so-called Messtischblatt, are particularly helpful [22]. Unfortunately, they were prepared only for some regions in Europe, and they are not always available. It is also worth emphasising that modern Polish maps at a scale of 1:25,000, as well as thematic maps (hydrographic at a scale of 1:50,000), present the layout of the water network in a simplified way, making it impossible to determine the type of inflow and/or outflow from the lake (natural or artificial). In such cases, field research is necessary. 


\section{Conclusions}

The criteria of classification of lakes in the Polish law result in numerous difficulties related to the application of law and implementation of water policy. Long-lasting court disputes have been observed for a dozen years. Parties in the disputes are entities managing water resources of the State Treasury and private entities, usually the owners of lakes. Should it turn out that the lake subject to a dispute constitutes flowing water, based on the law it belongs to the State Treasury, irrespective of any other aspects. Simultaneously, improper classification of lakes by public entities largely results from inaccurate and difficult to apply in practice classification criteria resulting from the water law changing over the years. Courts recognise the difficulty and complexity of the problem of classification of lakes. Due to this, they often appoint several experts (specialists in different areas) for the purpose of eliminating potential errors. Sometimes judges even participate in field visions to fully understand the complexity of the environmental and remaining conditions. Therefore, according to the authors, the legal classification of Polish lakes should be simplified and consider the episodic character of the inflow and/or outflow from the lake. It should also introduce a transparent criterion of maximum surface area of a lake that can constitute private property. Moreover, in the case of determination that a lake purchased in good will as stagnant water does not meet the criteria of this type of waters, the authors postulate the introduction of mechanisms permitting compensation of the incurred losses. This would result in an increase in the trust of society to the law, and would reduce fears related to purchasing lakes by potential buyers. It would increase the efficiency of different purposes of water policy in reference to lakes.

Provisions developing water policy in different countries in reference to lakes are incoherent. This results from different approaches to the issues of classification and ownership of lakes, as well as solutions applied in particular legislatures. Due to the variability of conditions of occurrence of lakes, their social importance, or economic development of the country or region, the debate in the scope constitutes a field for discussions and disputes. This confirms the complexity of the problem. According to the authors, the consequences of the dualist division of lakes in Polish law sometimes do not correspond with the debate conducted in the state based on justice and integrity.

Author Contributions: Conceptualization, W.M. and M.M.; Methodology, W.M. and M.M.; Validation, W.M. and M.M.; Formal Analysis, W.M. and M.M.; Investigation, (hydrological) W.M. and (legal) M.M.; Resources, W.M. and M.M.; Writing-Original Draft Preparation, W.M. and M.M.; Writing-Review \& Editing, W.M. and M.M.; Visualization, W.M.; Supervision, W.M.; Funding Acquisition, W.M. and M.M.

Funding: This research was funded by Faculty of Earth Sciences Nicolaus Copernicus University in Torun and Faculty of Law and Administration Nicolaus Copernicus University in Torun, Poland.

Acknowledgments: The authors would like to thank Katarzyna Kubiak-Wójcicka and Bożena Pius for the help in conducting field research in Lake Stacinko catchment. Furthermore, we would like to thank Sławomir Brózda and Jakub Sznajder for their cooperation during field research in Lake Strzemiuszczek catchment. We are also grateful to the anonymous reviewers for their valuable comments to our manuscript.

Conflicts of Interest: The authors declare no conflict of interest.

\section{References}

1. Dellapenna, J.W.; Gupta, J. The Evolution of Global Water Law. In The Evolution of the Law and Politics of Water; Springer Science + Business Media B.V.: Dordrecht, The Netherlands, 2009; ISBN 978-1-4020-9866-6.

2. Canelas de Castro, P. European Community Water Policy. In The Evolution of the Law and Politics of Water; Springer Science + Business Media B.V.: Dordrecht, The Netherlands, 2009; ISBN 978-1-4020-9866-6.

3. Block, W.; Nelson, P.L. Water Capitalism: The Case for Privatizing Oceans, Rivers, Lakes and Aquifers; Lexington Books: New York, NY, USA, 2015; ISBN 978-1-4985-1881-9.

4. Directive 2000/60/EC of the European Parliament and of the Council as of 23 October 2000 Establishing the Framework of Community Measures in the Scope of Water Policy. Available online: https:/ / eur-lex.europa. eu/legal-content/EN/TXT/HTML/?uri=CELEX:32000L0060\&from=PL (accessed on 31 August 2018). 
5. Glazik, R.; Marszelewski, W. Hydrological Classification of Lake Radodzierz Within the Meaning of the Water Law; Expert Report; District Court in Świecie: Świecie, Poland, 2001.

6. Varjopuro, R.; Salmi, P. The Functionality of Fisheries Management from the Perspective of Commercial Fishermen. Two Cases in Comparison. In Alternative Management Systems for Fisheries; Blackwell Science Ltd.: Oxford, UK, 1999; ISBN 0-85238-262-6.

7. Górlikowski, M. He Lost a Private Lake. Available online: http://trojmiasto.wyborcza.pl/trojmiasto/1, 35612,10480555,Stracil_prywatne_jezioro_bo__zadarl_z_letnikami.html (accessed on 30 September 2018).

8. Drewka, W. The End of the Battle for Lake Stacinko? The Owner Wants to Sue Prosecution. Available online: http:/ / expresskaszubski.pl/pl/11_wiadomosci/23017_msciszewice_koniec_batalii_o_ jezioro_stacinko_wlasciciel_chce_pozwac_prokurature.html\# (accessed on 30 September 2018).

9. Douglas, J.K. Public Recreation and the Navigability Test: State v. McIlroy, 595 S.W.2d 659 (1980). Urb. L. Ann. 1981, 21, 287-300.

10. Minnesota Department of Natural Resources. Available online: https://files.dnr.state.mn.us/publications / waters/Pardon_Me_Myth.pdf (accessed on 31 August 2018).

11. Justia US Supreme Court. The Daniel Ball, 77 U.S. 557. 1870. Available online: https://supreme.justia.com/ cases/federal/us/77/557/ (accessed on 31 August 2018).

12. Justia US Supreme Court. United States v. Oregon, 295 U.S. 1. 1935. Available online: https://supreme. justia.com/cases/federal/us/295/1/ (accessed on 31 August 2018).

13. Davis, P.N. State Ownership of Beds of Inland Waters-Summary and Reexamination. Neb. L. Rev. 1978, 57, 665-703.

14. Negotiable, I. The Ownership of Land under Waters. Harv. L. Rev. 1913, 27, 80-82. [CrossRef]

15. Starr, M. Navigable Waters of the United States. State and National Control. Harv. L. Rev. 1921, 35, $154-181$. [CrossRef]

16. Echo Press. Available online: http://www.echopress.com/news/4025855-you-asked-who-owns-lake (accessed on 31 August 2018).

17. Farnham, H.P. The Law of Waters and Water Rights: International, National, State, Municipal and Individual, Including Irrigation, Drainage, and Municipal Water Supply Vol. 1; Reprinted 2006; The Lawbook Exchange: Clark, NJ, USA, 2006; ISBN 13 978-1-58477-689-5.

18. Humbach, J.A. Public Rights in the Navigable Watercourses of New York. Pace Envtl. L. Rev. 1989, 6, 461-564.

19. The Baltic Course. Available online: http://www.baltic-course.com/eng/real_estate/?doc=91801 (accessed on 31 August 2018).

20. Salmi, P.; Varjopuro, R. Private Water Ownership and Fisheries Governance in Finland. In Proceedings of the IIFET 2000 Conference, Corvallis, OR, USA, 10-13 July 2000.

21. Alamaro, M. Water politics must adapt to a warming world. Nature 2014, 514. [CrossRef] [PubMed]

22. Marszelewski, W.; Brózda, S.; Marszelewski, M. The usefulness of archival cartographic materials in the legal classification of lakes in Poland. In Air and Water Components of the Environment, Cluj-Napoca, Romania, 17-19 March 2017; Casa Cărţii de Ştiinţa: Cluj-Napoca, Romania, 2017; pp. 159-165.

(C) 2018 by the authors. Licensee MDPI, Basel, Switzerland. This article is an open access article distributed under the terms and conditions of the Creative Commons Attribution (CC BY) license (http://creativecommons.org/licenses/by/4.0/). 